\title{
A new species of Phyllurus (Lacertilia : Gekkonidae) and a revised phylogeny and key for the Australian leaf-tailed geckos
}

\author{
C. J. Hoskin ${ }^{\mathrm{A}}$, P. J. Couper ${ }^{\mathrm{B}}$ and C. J. Schneider ${ }^{\mathrm{C}}$ \\ ${ }^{A}$ Department of Zoology and Entomology, University of Queensland, Brisbane, Qld 4072, Australia. \\ ${ }^{\mathrm{B}}$ Queensland Museum, PO Box 3300, South Brisbane, Q1d 4101, Australia. \\ ${ }^{\mathrm{C}}$ Department of Biology, Boston University, Boston, MA 02215, USA.
}

\begin{abstract}
Phyllurus gulbaru, sp. nov., is a highly distinct species of leaf-tailed gecko restricted to rocky rainforest of Pattersons Gorge, north-west of Townsville. The possession of a cylindrical, non-depressed, tapering original and regenerated tail separates $P$. gulbaru from all congeners except $P$. caudiannulatus. From this species $P$. gulbaru is separated by having a partially divided, as opposed to fully divided, rostral scale. Furthermore, the very small spinose body tubercles of $P$. gulbaru are in marked contrast to the large spinose body scales of $P$. caudiannulatus. An analysis of $729 \mathrm{bp}$ of mitochondrial $12 \mathrm{~S}$ rRNA and cytochrome $b$ genes reveals $P$. gulbaru to be a deeply divergent lineage with closer affinities to mid-east Queensland congeners than the geographically neighbouring $P$. amnicola on Mt Elliot. In conservation terms, $P$. gulbaru is clearly at risk. Field surveys of Pattersons Gorge and the adjacent ranges indicate that this species is restricted to a very small area of highly fragmented habitat, of which only a small proportion receives a degree of protection in State forest. Further, there is ongoing, unchecked destruction of dry rainforest habitat by fire. Under current IUCN criteria, P. gulbaru warrants an Endangered $(B 1,2)$ listing.
\end{abstract}

\section{Introduction}

Explorations in the rainforest of Queensland continue to lead to the discovery of remarkable new vertebrate species (e.g. Couper et al. 1993, 1996, 2000; Covacevich et al. 1993; Richards et al. 1994; McDonald 1997). In recent times most of these have been discovered in remote isolated patches of rainforest. Such species tend to have extremely localised distributions reflecting historical contraction and isolation of rainforest, and the effects of human activity over more recent time. Of particular interest over the last decade have been the leaf-tailed geckos (Phyllurus, Saltuarius and Orraya). Targeted surveys of small isolated rainforest patches along the Queensland coast, coupled with detailed morphological and molecular studies, have greatly advanced our knowledge of these geckos (Couper et al. 1993, 1997, 2000). This is reflected in 12 species currently recognised across three genera (Couper et al. 2000) as opposed to four species in one genus a decade ago (Covacevich 1975; Bauer 1990).

Couper et al. (2000) presented a phylogeny of the leaf-tailed geckos in which Saltuarius and Phyllurus were shown to be monophyletic groups. Saltuarius occultus Couper, Covacevich \& Moritz 1993, from McIlwraith Range, was recognised as a deeply divergent lineage basal to Saltuarius and Phyllurus. Re-evaluation of the morphological data, combined with new molecular information, resulted in reassignment of this species at the generic level: Orraya occultus (Couper, Covacevich \& Moritz 1993). The molecular data showed the leaf-tail geckos to represent ancient lineages, with the split between Saltuarius and Phyllurus dated at c. 58-74 million years ago and the divergence among species in the mid-east Queensland (MEQ) clade of Phyllurus being c. 31-38 million years ago. Thus it 
was postulated that the MEQ Phyllurus represent the relictual distribution of an ancient group separated by pre-Pleistocene contraction of rainforest.

Here we present the description of a new, highly distinct, species of Phyllurus, the most northerly member of the genus. Mitochondrial DNA sequencing allows the phylogeny presented in Couper et al. (2000) to be revised to include this species. Additionally, an updated key to the leaf-tailed geckos is included.

\section{Methods}

Morphometrics

All measurements were taken using Mitutoyo electronic callipers. Supralabials, infralabials and subdigital lamellae were counted on both sides of specimens examined. These are presented as separate left/right counts for the holotype data and as a mean and mode elsewhere. External morphological characters follow Covacevich (1975) and Couper et al. (1993). Skeletal definitions follow Bauer (1990). The following abbreviations apply: snout to vent length (SVL); tail length (T), from posterior margin of cloaca to tip of tail; attenuated tip of original tail (TT); head length (HL); head width (HW); snout length (S). Additional measurements include: length of front leg (L1) axilla to tip of longest digit; length of hind leg (L2) groin to tip of longest digit; neck length (NL) axilla to posterior margin of ear; neck width (NW) width across narrowest point.

All specimens examined are held in the Queensland Museum. Comparisons with other Phyllurus spp. are based on Covacevich (1975) and Couper et al. (1993, 2000).

Molecular systematics

In addition to the material cited in Couper et al. (2000), liver samples from P. gulbaru (QMJ75778 and QMJ78069) were also examined.

Portions of the mitochondrial 12S rRNA and cytochrome $b$ genes were amplified and sequenced using primers 12Sa and 12Sb (Palumbi 1996) and Ph-1 and cyt-b2 (Couper et al. 1997) respectively. PCR conditions were as described in Couper et al. (1997). Products were gel-purified and sequenced on an ABI 377 automated sequencer following standard dye-termination sequencing protocols. The resulting data-set consisted of 811 nucleotides, 399 base pairs (bp) corresponding to codons 1-133 of the cytochrome $b$ gene, and 412 aligned $\mathrm{bp}$ of the 12S rRNA gene. Sequences from the protein-coding cytochrome $b$ gene were unambiguously aligned using the translated amino acid sequence. Sequences from the 12S rRNA gene were aligned using a model of secondary structure (Hickson et al. 1996). Areas of ambiguous alignment were excluded from subsequent analyses due to our lack of confidence in positional homology. The final data-set contained 729 bp of aligned mtDNA sequence from all species of Phyllurus, Saltuarius, Orraya and Carphodactylus.

For phylogenetic analysis we used a Bayesian approach as implemented in MRBAYES (Huelsenbeck and Ronquist 2001; for reviews of Bayesian analysis see Huelsenbeck et al. 2001; Lewis 2001). We specified a General Time Reversible model of nucleotide substitution with gamma-distributed rate variation among nucleotide sites and a proportion of invariant sites. All parameters of the nucleotide substitution model (nucleotide frequency, transition probabilities for each nucleotide change, proportion of invariant sites, and the shape of the gamma distribution) were estimated simultaneously with the tree search. We ran four separate Markov-Chain Monte Carlo (MCMC) chains with random starting parameters for 500000 generations. The values on the branches represent the probability that the subsequent clade occurs in the majority-rule consensus of 10000 trees resulting from sampling every 10 generations for the last 100000 MCMC generations. This value reflects the proportion of times the MCMC simulation resulted in a tree with that clade and is a meaningful measure of support (i.e. the posterior probability of that clade).

\section{Systematics}

The new species is assigned to Phyllurus on the basis of mtDNA sequence data and by the following synapomorphies (after Bauer 1990): anteriormost autotomy septum in fifth caudal vertebra; postmental scales subequal (not enlarged); tail terminating in a small knob; and males without preanal pores. This assignment is supported further by the following character states (after Couper et al. 1993): nostril not in contact with rostral shield; rostral partially divided; tail tip finely attenuated; and axilla invaginated. 
Phyllurus gulbaru, sp. nov. (Gulbaru gecko)

(Fig. 1)

\section{Holotype}

QMJ75778, ơ (original tail), Palm Tree Ck, Paluma Range (19 $\left.20^{\prime} \mathrm{S}, 146^{\circ} 28^{\prime} \mathrm{E}\right)$, north-east Queensland (NEQ), C. Hoskin, G. Dolman, A. Mousalli, G. Joseph and A. Lane, 6 March 2001.

\section{Holotype data}

QMJ75778, Male; SVL 89.9 mm; L1 41.2 mm; L2 48.8 mm; T 81.0 mm; TT 17.0 mm; HL $23.9 \mathrm{~mm}$; HW $20.2 \mathrm{~mm}$; S $11.3 \mathrm{~mm}$; NL $18.6 \mathrm{~mm}$; supralabials $14 / 15$; infralabials $13 / 14$; subdigital lamellae 17/17.

\section{Paratypes}

QMJ78069, ô (regenerated tail), collection details as for holotype; QMJ78123, ㅇ (original tail), Pattersons Gorge, Paluma Range $\left(19^{\circ} 17^{\prime} \mathrm{S}, 146^{\circ} 29^{\prime} \mathrm{E}\right)$, NEQ, C. Hoskin and M. Higgie, 3 December 2001.

\section{Diagnosis}

P. gulbaru, sp. nov., is the only Phyllurus with a partially divided rostral scale and a cylindrical, tapering, non-depressed tail (original and regenerated).

\section{Description}

SVL $(\mathrm{mm})$ : $81.2-89.4(n=3$, mean $=86.6)$. Proportions as \% SVL: L1 46.8-47.5 $(n=3$, mean $=47.1)$; L2 54.1-57.1 $(n=3$, mean $=55.5)$; T 87.2-88.9 $(n=2$, mean $=88.1)$; HL 27.1-29.3 $(n=3$, mean = 28.2); HW 22.3-23.3 $(n=3$, mean $=22.6)$; S 11.8-12.3 $(n=3$, mean $=12.1)$; NL 17.8-19.2 $(n=3$, mean $=18.5)$; NW 8.6-9.7 $(n=3$, mean $=9.1)$.

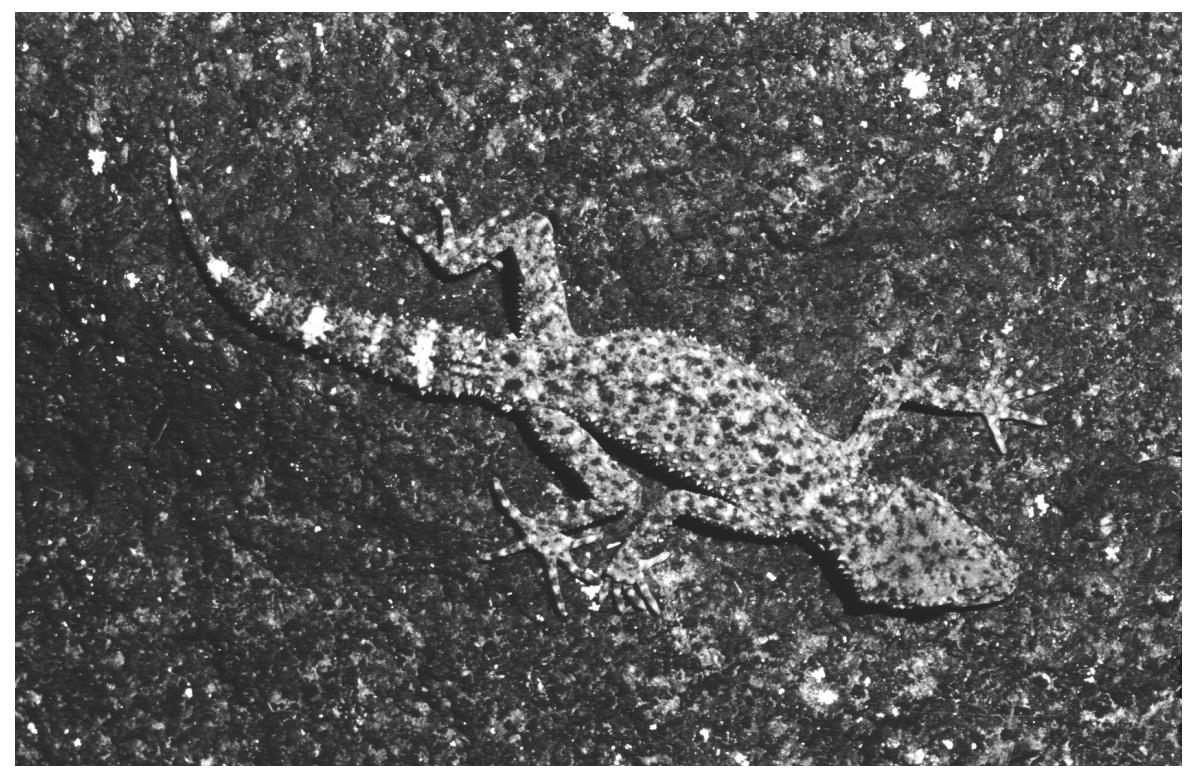

Fig. 1. Phyllurus gulbaru, sp. nov. (holotype, QMJ75778), Pattersons Gorge, NEQ (Conrad Hoskin). 
Head: Large, depressed, triangular, distinct from neck; covered in very small granules with larger pale conical tubercles at back and sides of head; skin of head co-ossified with skull; deep, vertical groove partially dividing rostral scale $(n=3)$; rostral not in contact with nostril; 6-7 scales along the dorsal margin of rostral shield $(n=3)$; ear opening elliptical, vertical, much less than half as large as eye, raised projection overhangs upper margin of ear; supralabials $13 / 14(n=3$, mean $=13.7$, mode $=14)$; infralabials $13-15(n=3$, mean $=$ 13.8 , mode $=14)$; eyelids with blue tinge in life; tongue with terminal groove, anterior half purple/blue in life, dark grey in preservative. Neck: broad NW \% HW: 38.4-41.5 $(n=3$, mean $=40.3)$, covered in small granules that are intermixed with larger pale conical tubercles. Body: depressed, covered in small granules; flank granules intermixed with larger pale conical tubercles; tubercles very small on back; basal scales surrounding flank tubercles not enlarged; no enlarged tubercles or granules on ventral surface of body. Preanal pores absent. Axilla deeply invaginated. Limbs: long, covered in small pointed tubercles dorsally; lacking enlarged tubercles on ventral surface, except on upper forelimb; digits strong, strongly compressed distally; subdigital lamellae (fourth toe) $16 / 17(n=3$, mean $=$ 16.7 , mode $=17)$. Male preanal organs enlarged $(n=2)$ with conspicuous cloacal spurs on anterior-lateral margin. Original tail: $(n=2)$ cylindrical, slightly depressed, not flared, contracted at base and attenuated at tip, terminating with a minute rounded white 'knob'; dorsal surface, except for attenuated tip, with prominent enlarged spinose tubercles especially along margins and at tail base; small tubercles on distal one-quarter of tail and minute granules on attenuated tail-tip; ventral surface smooth with a mosaic of fine round scales. Regenerated tail: $(n=1)$ slightly depressed, cylindrical, bulbous at base and tapering to tip; covered with uniform granules, aligned in fine concentric rings for the full length of the tail, no spinose tubercles.

Additionally measurements ( $\mathrm{mm}$ ) were taken in the field (CJH, 3 December 2001) of 4 males: SVL 84.0-87.0 $($ mean $=85.5)$, regenerated TL 30.0-57.0 $($ mean $=47.3) ; 3$ gravid females (each with 2 eggs): SVL 92.0-93.0 (mean = 92.3), regenerated TL 50.0-63.0 $($ mean $=55.3)$; 1 immature female: SVL 76.0, regenerated TL 38; and 1 juvenile: SVL 54.0, original TL 41.0.

\section{Pattern}

In spirit, dorsal base colour grey with irregular dark blotches on head, body and limbs; blotches on body may tend to align roughly transversely $(n=1)$ or align along the dorsal mid-line $(n=2)$; a pair of large dark and white blotches immediately anterior to tail base. Blotches aligned transversely on limbs; digits strongly banded; inner anterior digit with only slightly reduced pigment. Body and limbs ventrally off-white to cream (immaculate), slight peppering on chin and blotching ventrally on upper forelimb; pectoral and postcloacal regions also with darker pigmentation; labials off-white, mottled with brown. Original tail dorsally grey, marked with irregular dark blotches showing some alignment along mid-line; eight cream bands on tail, 2 and 4 poorly defined, only those on attenuated portion (4) extend to ventral surface, distal 'knob' white; ventrally cream, peppered with brown specks. Regenerated tail lacking cream bands; dorsally grey, mottled with irregular dark blotches; ventral surface similar, but with reduced pigmentation.

\section{Skeletal and soft tissue features}

Material examined: (radiographs) QMJ75778, QMJ78069. Supraocular portion of frontal grooved; presacral vertebrae 26; sacral vertebrae 2; lumbar vertebrae 2; first autotomy septum on postsacral vertebra 5 ; abdominal vertebrae bearing reduced ribs 4 ; 


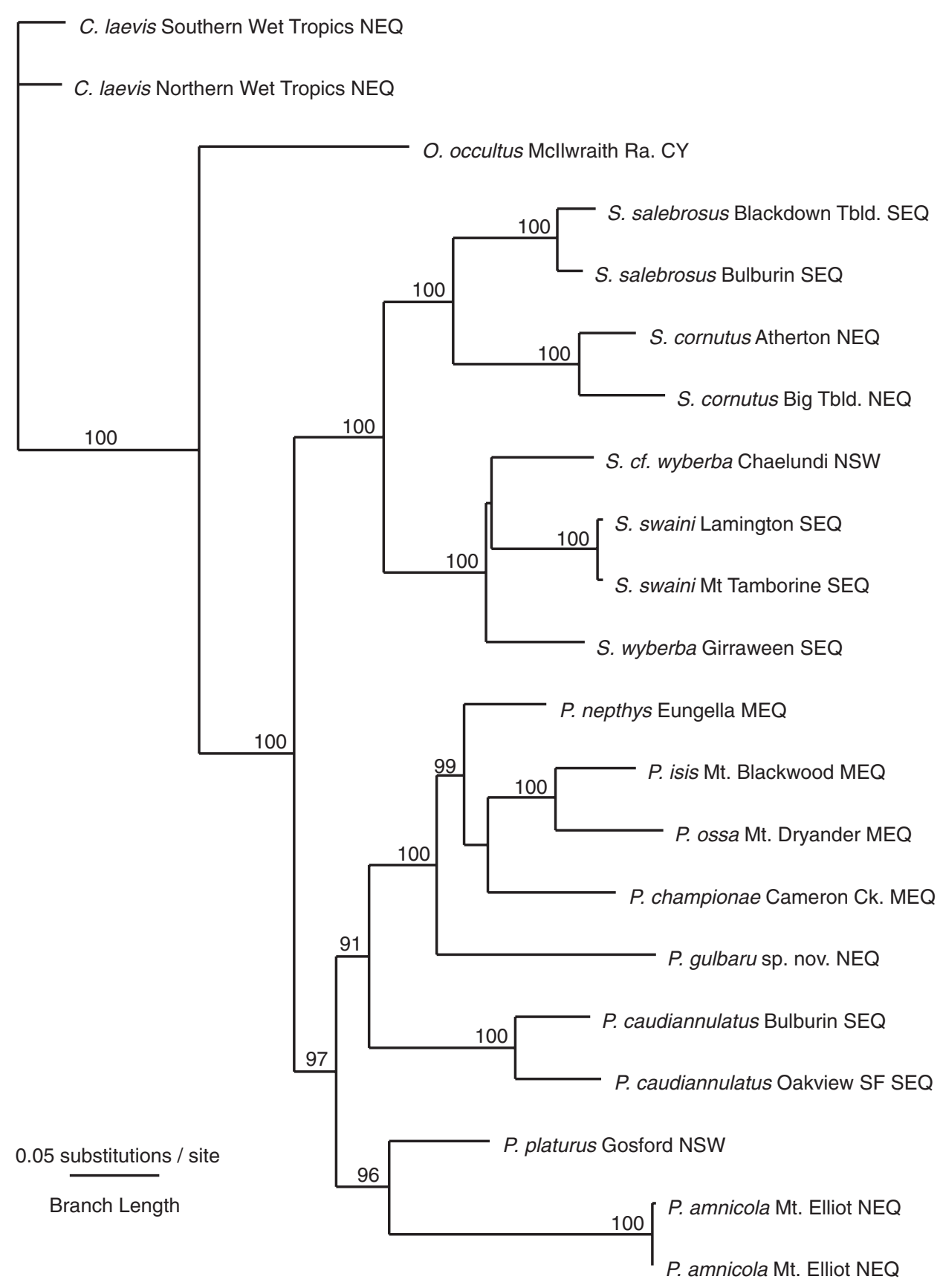

Fig. 2. Phylogeny of leaf-tailed geckos (Orraya, Saltuarius and Phyllurus) based on Bayesian Analysis of 729 bp of mitochondrial $12 \mathrm{~S}$ rRNA and cytochrome $b$ genes. Sequences from Carphodactylus laevis were used as an outgroup to root the tree and posterior probabilities are presented (see Appendix for locality details). Possible new species are here referred to Saltuarius cf. wyberba pending collection of more specimens (see Couper et al. 2000). CY, Cape York; NEQ, north-east Queensland; MEQ, mid-east Queensland; SEQ, south-east Queensland; NSW, New South Wales. 
rib-free cervicals 3; sternal ribs 3; mesosternal ribs 2 . The small size of the type series did not allow for the preparation of an alizarin-stained specimen. Hence, we were unable to assess the nature of the anterior process of the interclavicle or the size of the epipubic cartilage.

\section{Comparison}

P. gulbaru can be separated from its congeners, with the exception of $P$. caudiannulatus, by the possession of a cylindrical, non-depressed, tapering original and regenerated tail. $P$. gulbaru can be separated from $P$. caudiannulatus by having a partially divided rostral scale as opposed to fully divided in the latter. Furthermore, the spinosity of $P$. caudiannulatus is in marked contrast to the very small spinose body tubercles of P. gulbaru.

\section{Etymology}

'Gulbaru' is the Aboriginal language name for the Paluma Range (HEMA 1999; Faith Baisden, FATSIL, personal communication). The epithet is to be treated as a noun in apposition.

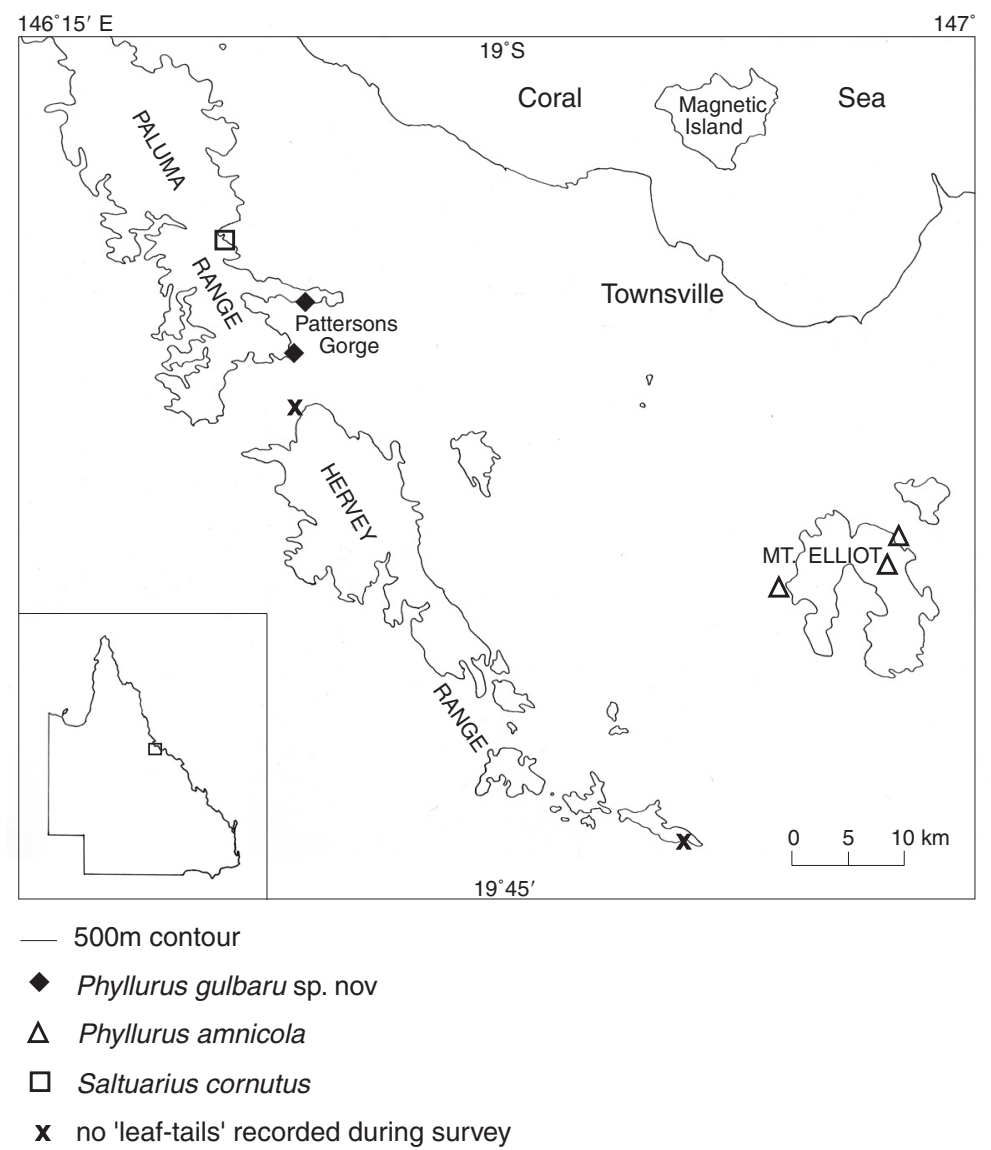

Fig. 3. Leaf-tailed gecko survey records for southern Paluma Range, Hervey Range and Mt Elliot. Surveys were conducted by CJH between February 1998 and April 2002. 


\section{Genetics}

The tree presented in Fig. 2 is the best estimate of relationships given the model of nucleotide substitution and the data. Parsimony analyses with various weighting schemes and ML analyses with the same nucleotide substitution model resulted in similar trees. Posterior probabilities on the branches indicate that there is strong support for most of the clades. Monophyly of Phyllurus is well supported and within this genus P. gulbaru is
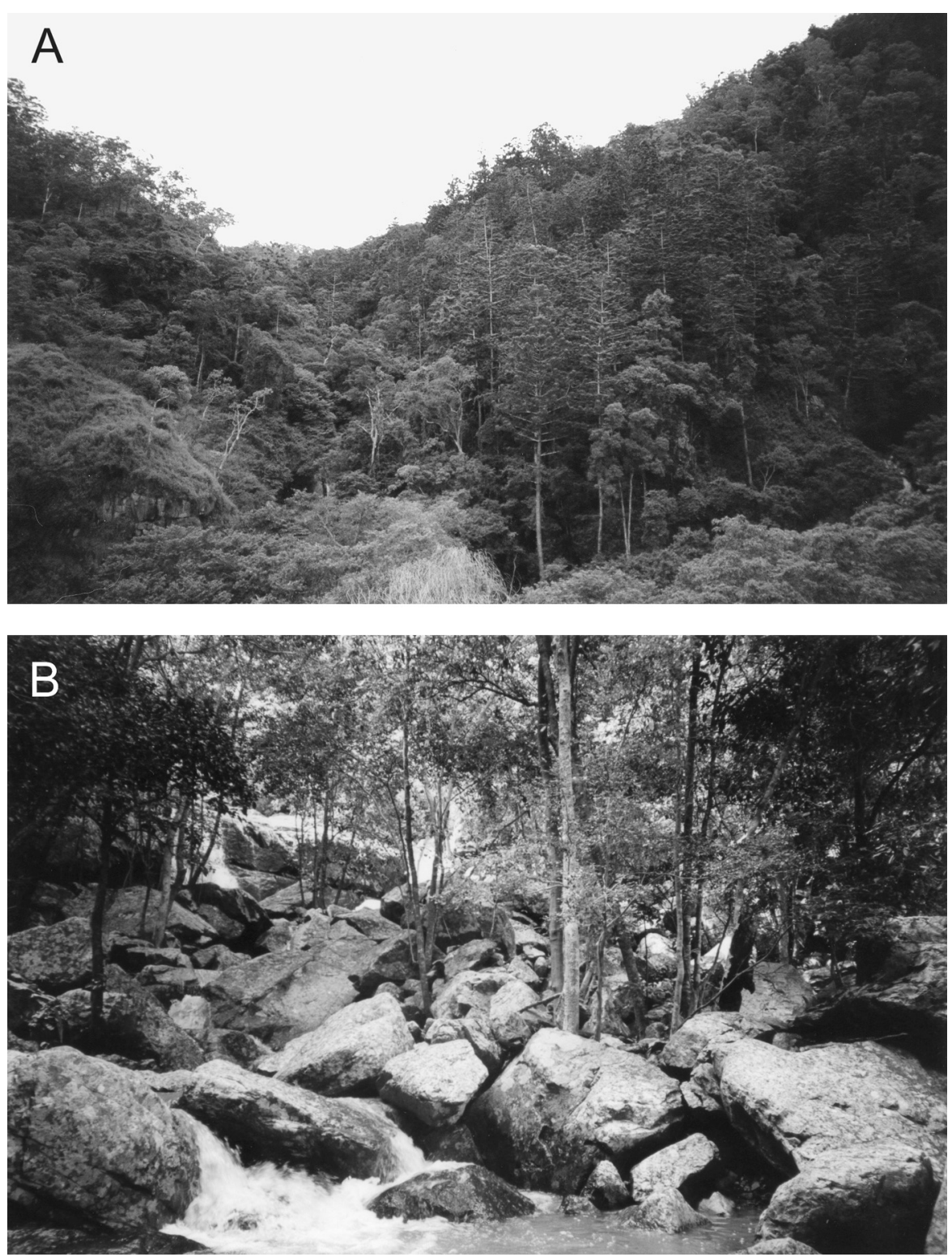

Fig. 4. (A) Araucaria cunninghamii-dominated rainforest gully and open Eucalyptus woodland in Pattersons Gorge, Paluma Range, NEQ - the type locality of $P$. gulbaru, sp. nov. (B) Rocky streamside rainforest in Pattersons Gorge, typical habitat for $P$. gulbaru, sp. nov. (Conrad Hoskin). 
strongly supported as a deeply divergent lineage basal to the mid-east Queensland species. The geographically neighbouring species, $P$. amnicola, is not closely related to P. gulbaru and represents a deep, basal lineage within Phyllurus that is placed by this analysis as the sister species to P. platurus of the 'Sydney Sandstone'.

\section{Distribution}

All individuals have been collected from Pattersons Gorge on the extreme southern end of the Paluma Ra. (37 km west of Townsville), at Palm Tree Creek (19 $\left.20^{\prime} \mathrm{S}, 146^{\circ} 28^{\prime} \mathrm{E}\right)$ and on an unnamed tributary of Black River $\left(19^{\circ} 17^{\prime} \mathrm{S}, 146^{\circ} 29^{\prime} \mathrm{E}\right)$, NEQ (Fig. 3). Surveys in the rainforest to the north and south of Pattersons Gorge have failed to locate this species (Fig. 3).

\section{Habitat}

Found amongst boulders in gullies of Hoop Pine (Araucaria cunninghamii) dominated microphyll to notophyll vine forest (Fig. 4A, B). Such gullies are set in a matrix of open Eucalyptus woodland. Oedura rhombifer and Gehyra dubia were also encountered in this habitat.

\section{Habits}

All individuals have been found at night amongst boulders and rock fissures in close proximity to a stream. Most individuals were found head down on vertical rock surfaces, a few were in rock fissures and one was foraging low on a slender tree trunk amongst boulders. Activity began soon after dark. Of 12 individuals (60, $5 \%$ and 1 juvenile) encountered over two nights, $75 \%$ had regenerated tails, a similar proportion to that seen in P. amnicola (Couper et al. 2000).

\section{Reproduction}

Four gravid females encountered on 3 December 2001 each contained two shelled eggs. One female was collected and laid two oval-shaped eggs in captivity two weeks later. After incubation in vermiculite at $26^{\circ} \mathrm{C}$ for approximately 60 days the eggs failed. Fully formed embryos were found on dissection. Both males, collected in early March, were sexually mature and in peak reproductive condition with sperm present in the epididymis (inferred from opacity) and turgid testis. From this we infer that mating may occur at least until autumn and that females store sperm through winter. A similar reproductive strategy has been suggested for P. platurus (Greer 1989).

\section{Discussion}

Biogeography

Surveys to date indicate that $P$. gulbaru is restricted to two sub-populations in Pattersons Gorge (Fig. 3). Suitable habitat exists immediately to the north on the Paluma Range; however, during a recent survey no Phyllurus were located but rather Saltuarius cornutus was found amongst boulders in the catchment of Bluewater Creek $\left(19^{\circ} 14.383^{\prime} \mathrm{S}\right.$, $146^{\circ} 24.689^{\prime} \mathrm{E}$, altitude $450 \mathrm{~m}$ ) (Fig. 3). This represents a new locality record for this species, the most southerly to date. Leaf-tailed gecko species are known to coexist at only one locality (Many Peaks Range: S. salebrosus and P. caudiannulatus: Couper et al. 2000) and it is possible that competition has limited the distribution of either, or both, P. gulbaru and S. cornutus in this area. Another possible explanation for the distribution of these two 
species relates to the past and present distribution of rainforest along the Paluma Range. The rainforest-restricted vertebrates of the Wet Tropics have recolonised much of their current distributions from Pleistocene refugia (Schneider et al. 1998). Currently, there is a narrow break in the distribution of rainforest along the Paluma Range immediately to the north of Pattersons Gorge. Such a dry barrier may have limited the southerly expansion of some rainforest species, such as S. cornutus, into Pattersons Gorge.

The rainforest of Pattersons Gorge contains a depauperate subset of the vertebrate fauna of the Wet Tropics, and it is here that many species reach the southern limit of their range (e.g. Carlia rubrigularis, Lampropholis coggeri, Dactylopsila trivirgata) (CJH survey data). The presence of P. gulbaru, a narrowly distributed species with its closest affinities to taxa in mid-east Queensland, in Pattersons Gorge is therefore of great interest. Genetic data do not suggest the persistence of refugial populations of L. coggeri $(\mathrm{CJH}$, unpublished data) in Pattersons Gorge; rather, that they recolonised from the north. However, the persistence of $P$. gulbaru would suggest that there was historical retention of at least small areas of rainforest in the southern Paluma Range. P. gulbaru highlights the ability of Phyllurus to persist in small remnants of rainforest, possibly due to their association with rocky microhabitats. Therefore, it is suggested that the rainforest fauna of Pattersons Gorge is primarily composed of Wet Tropics taxa via filtered recolonisation from the north. The discovery of $P$. gulbaru now shows that it contains at least one product of in situ or parapatric speciation from a group with a more southerly distribution.

Prior to the discovery of P. gulbaru, P. amnicola was the only other Phyllurus known in NEQ and was seen as the northern relative to the mid-east Queensland species ( $P$. isis, $P$. ossa, P. championae and P. nepthys) and those further to the south (P. caudiannulatus in south-east Queensland and P. platurus in the Sydney region) (Couper et al. 2000). The deeply divergent nature of $P$. amnicola was believed to reflect ancient separation of this species from those further to the south as rainforest contracted. A well recognised historical dry barrier, the 'Burdekin Gap' (Joseph et al. 1993), separates the rainforests of Mt Elliot and Paluma from those to the south. The discovery of $P$. gulbaru now indicates that $i t$ is in fact the sister taxon to the mid-east Queensland species, from which it has diverged across the Burdekin Gap. This finding further supports an ancient link between the rainforests of mid-east Queensland and the Wet Tropics (Joseph et al. 1993). P. amnicola, the geographical neighbour of $P$. gulbaru, is now seen to represent a deeply divergent basal lineage within Phyllurus rather than the sister taxon of P. gulbaru, as might be expected. The genetic data highlight the ancient origins and complex history of the rainforest taxa of the east coast and the importance of small, isolated rainforest remnants such as Mt Elliot and Pattersons Gorge in preserving remnant populations.

\section{Conservation}

Phyllurus gulbaru is one of the most narrowly restricted reptile species in Queensland, with conservative estimates of 'areas of occurrence' and 'occupancy' being $23 \mathrm{~km}^{2}$ and $14 \mathrm{~km}^{2}$ respectively (criteria defined by IUCN Species Survival Commission 1994). IUCN criteria define Endangered as 'area of occurrence' less than $5000 \mathrm{~km}^{2}$ or 'area of occupancy' less than $500 \mathrm{~km}^{2}$ in conjunction with estimates of fragmentation, decline or fluctuations in populations, habitat area or quality. Such a limited distribution would not be of such concern if most of habitat were protected (e.g. P. isis in Mt Blackwood National Park: Couper et al. 1993; P. amnicola in Bowling Green Bay National Park: Couper et al. 2000). However, Pattersons Gorge falls just south of the Wet Tropics World Heritage boundary and only a small fraction of the suitable habitat for $P$. gulbaru receives some degree of 
protection in Mt Cataract State Forest. Surveys indicate that P. gulbaru probably occurs in two subpopulations within Pattersons Gorge that are separated by an expanse of unsuitable habitat. Transfer of Mt Cataract State Forest to a 'Forest Reserve' would provide greater protection to a portion of the habitat occupied by one of these sub-populations.

The reduction and fragmentation of patches of suitable habitat by fire poses a threat to the survival of this species. The apparent restriction of P. gulbaru (as for most Phyllurus) to steep rocky areas may afford some degree of protection from fire. However, the seven species of Phyllurus in Queensland are rainforest-restricted and the conversion of rainforest to Eucalyptus woodland by unmanaged burning must be recognised as a threat. Much of the suitable habitat at the type locality has already been destroyed by severe burning since the discovery of this species (CJH, personal observations). Furthermore, burning and grazing have the potential to lead to the isolation of small pockets of suitable habitat between which the geckos would have limited ability to move.

Phyllurus gulbaru must be considered a species under threat. Surveys to date indicate a very small and fragmented distribution, very little of which area is protected. Furthermore, the destruction of habitat by unmanaged burning continues to reduce and further fragment the available habitat. For these reasons Phyllurus gulbaru should be listed as Endangered $(B 1,2)$ (IUCN Species Survival Commission 1994).

\section{Key to the Australian leaf-tailed geckos (Phyllurus, Saltuarius and Orraya)}

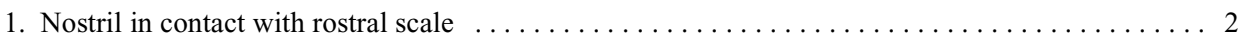

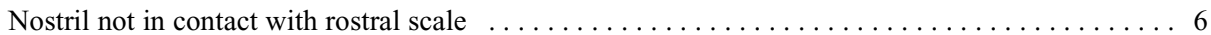

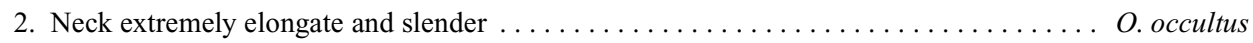

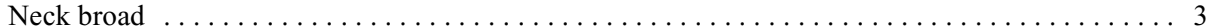

3. Throat strongly tuberculate $\ldots \ldots \ldots \ldots \ldots \ldots \ldots \ldots \ldots \ldots \ldots \ldots \ldots \ldots \ldots \ldots \ldots \ldots \ldots \ldots$ salebrosus

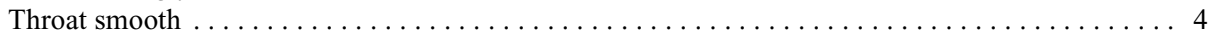

4. Lower flank tubercles hooked and surrounded by spinose, basal scutes $\ldots \ldots \ldots \ldots \ldots \ldots$. cornutus

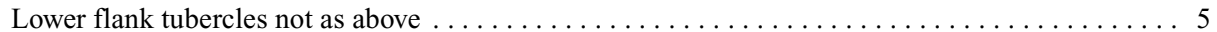

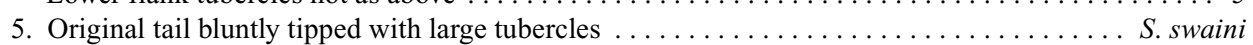
Original tail finely tipped with only minute tubercles $\ldots \ldots \ldots \ldots \ldots \ldots \ldots \ldots$. wyberba

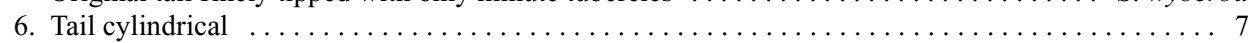

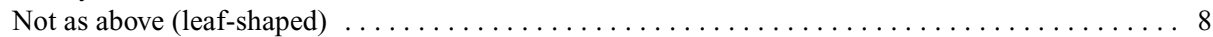

7. Rostral scale completely divided $\ldots \ldots \ldots \ldots \ldots \ldots \ldots \ldots \ldots \ldots \ldots \ldots \ldots \ldots \ldots \ldots \ldots$ caudiannulatus

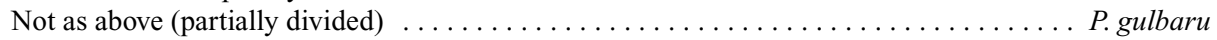

8. Anterior portion of original tail without white crossbands or blotches $\ldots \ldots \ldots \ldots \ldots$. platurus

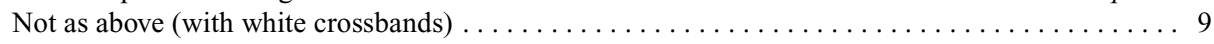

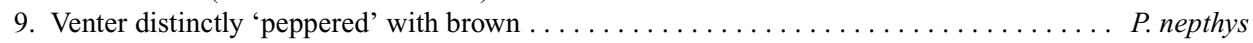

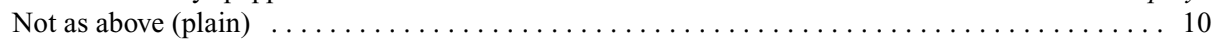

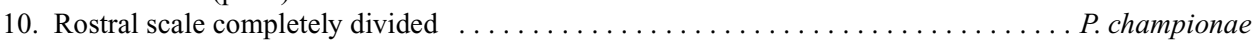

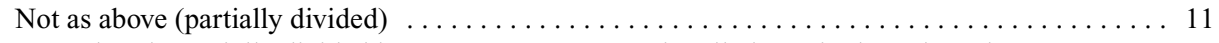

11. Rostral scale partially divided by 2 or 3 grooves, occasionally by a single Y-shaped groove

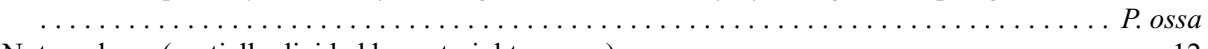

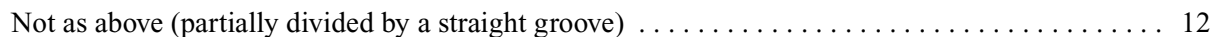

12. Anterior flared portion of original tail uniformly covered with enlarged spinose tubercles

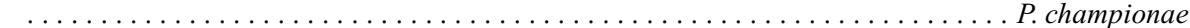

Not as above (spinose tubercles absent or few and scattered) $\ldots \ldots \ldots \ldots \ldots \ldots \ldots \ldots \ldots \ldots$

13. Tail predominantly black, with distinct white blotches present on either side of the vertebral line, SVL

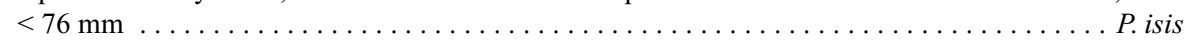

Not as above (tail predominantly tan/grey, with anterior most bands broken, but spanning tail width),

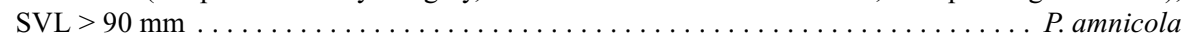




\section{Acknowledgments}

This work was supported financially by an NSF grant and the Queensland Museum. We are grateful for assistance in the field and in the preparation of this paper from: Megan Higgie, Gaynor Dolman, Grant Joseph, Adnan Mousalli, Amanda Lane, Jeremy Austin, Jeanette Kemp, Faith Baisden (FATSIL: Aboriginal and Torres Strait Islander Corporation of Languages) and two anonymous referees. We also thank the Howard Small Animal Clinic at the University of Queensland for $X$-raying the geckos for skeletal examination.

\section{References}

Bauer, A. M. (1990). Phylogenetic systematics and biogeography of the Carphodactylini (Reptilia: Gekkonidae). Bonner Zoologische Monographien 30, 1-217.

Couper, P. J., Covacevich, J. A., and Moritz, C. (1993). A review of the leaf-tailed geckos endemic to eastern Australia: a new genus, four new species, and other new data. Memoirs of the Queensland Museum 34, 95-124.

Couper, P. J., Covacevich, J. A., Marsterson, S. P., and Shea, G. M. (1996). Coggeria naufragus gen. et sp. nov., a sand-swimming skink from Fraser Island, Queensland. Memoirs of the Queensland Museum 39, 233-241.

Couper, P. J., Schneider, C. J., and Covacevich, J. A. (1997). A new species of Saltuarius (Lacertilia: Gekkonidae) from granite-based, open forests of eastern Australia. Memoirs of the Queensland Museum 42, 91-96.

Couper, P. J., Schneider, C. J., Hoskin, C. J., and Covacevich, J. A. (2000). Australian leaf-tailed geckos: phylogeny, a new genus, two new species and other new data. Memoirs of the Queensland Museum 45, $253-265$.

Covacevich, J. (1975). A review of the genus Phyllurus (Lacertilia: Gekkonidae). Memoirs of the Queensland Museum 17, 293-303.

Covacevich, J. A., Couper, P. J., and James, C. (1993). A new skink, Nangura spinosa gen. et sp. nov., from a dry rainforest of southern Queensland. Memoirs of the Queensland Museum 34, 159-167.

Greer, A. E. (1989). 'The Biology and Evolution of Australian Lizards.' (Surrey Beatty: Sydney).

HEMA (1999). Map: 'Townsville-Cairns-Cooktown'. 3rd Edn. (HEMA Maps Pty Ltd: Logan City.)

Hickson, R. E., Simon, C., Cooper, A., Spicer, G. S., Sullivan, J., and Penny, D. (1996). Conserved sequence motifs, alignment, and secondary structure for the third domain of animal 12s rRNA. Molecular Biology and Evolution 13, 150-169.

Huelsenbeck, J. P., and Ronquist, F. (2001). MRBAYES: Bayesian inference of phylogenetic trees. Bioinformatics 17, 754-755.

Huelsenbeck, J. P., Ronquist, F., Nielsen, R., and Bollback, J. P. (2001). Evolution - Bayesian inference of phylogeny and its impact on evolutionary biology. Science 294, 2310-2314.

IUCN Species Survival Commission (1994). 'IUCN Red List Categories.' (IUCN Council: Gland, Switzerland.)

Joseph, L., Moritz, C., and Hugall, A. (1993). A mitochondrial perspective on the historical biogeography of mideastern Queensland rainforest birds. Memoirs of the Queensland Museum 34, 201-214.

Lewis, P. O. (2001). Phylogenetic systematics turns over a new leaf. Trends in Ecology and Evolution 16, $30-37$.

McDonald, K. R. (1997). A new stream-dwelling Litoria from the Melville Ra., Queensland, Australia. Memoirs of the Queensland Museum 42, 307-309.

Palumbi, S. R. (1996). Nucleic acids. II: The polymerase chain reaction. In 'Molecular Systematics'. (Eds D. M. Hillis,. C. Moritz and B. K. Mable.) pp. 205-247. (Sinauer Associates Inc.: Sunderland, MA.)

Richards, S. J., Dennis, A. J., Trenerry, M. P., and Werren, G. L. (1994). A new species of Cophixalus (Anura: Microhylidae) from northern Queensland. Memoirs of the Queensland Museum 37, 307-310.

Schneider, C. J. S., Cunningham, M., and Moritz, C. (1998). Comparative phylogeography and the history of endemic vertebrates in the Wet Tropics rainforest of Australia. Molecular Ecology 7, 481-498. 


\section{Appendix. Details of collection localities of specimens used in genetic analysis}

Blackdown Tableland $\left(23^{\circ} 46^{\prime} \mathrm{S}, 149^{\circ} 06^{\prime} \mathrm{E}\right)$, Bulburin SF $\left(24^{\circ} 31^{\prime} \mathrm{S}, 151^{\circ} 29^{\prime} \mathrm{E}\right)$, Atherton $\left(17^{\circ} 16^{\prime} \mathrm{S}\right.$, $\left.145^{\circ} 29^{\prime} \mathrm{E}\right), \mathrm{MT}=$ Malbon Thompson Range $\left(17^{\circ} 05^{\prime} \mathrm{S}, 145^{\circ} 52^{\prime} \mathrm{E}\right), \mathrm{BT}=$ Big Tableland $\left(15^{\circ} 43^{\prime} \mathrm{S}, 145^{\circ} 17^{\prime} \mathrm{E}\right)$, Chaelundi SF $\left(30^{\circ} 01^{\prime} 07^{\prime \prime} \mathrm{S}, 152^{\circ} 30^{\prime} 02^{\prime \prime} \mathrm{E}\right.$ and $\left.30^{\circ} 03^{\prime} 04^{\prime \prime} \mathrm{S}, 152^{\circ} 21^{\prime} 36^{\prime \prime} \mathrm{E}\right)$, Girraween NP $\left(28^{\circ} 50^{\prime} \mathrm{S}\right.$, $\left.151^{\circ} 55^{\prime} \mathrm{E}\right)$, Lamington NP $\left(28^{\circ} 14^{\prime} \mathrm{S}, 153^{\circ} 08^{\prime} \mathrm{E}\right)$, Mt Tamborine $\left(27^{\circ} 55^{\prime} \mathrm{S}, 153^{\circ} 10^{\prime} \mathrm{E}\right)$, Eungella NP $\left(21^{\circ} 08^{\prime} \mathrm{S}, 148^{\circ} 30^{\prime} \mathrm{E}\right)$, Finch Hatton Gorge $\left(21^{\circ} 06^{\prime} \mathrm{S}, 148^{\circ} 38^{\prime} \mathrm{E}\right)$, Cameron Creek $\left(21^{\circ} 34^{\prime} 24^{\prime \prime} \mathrm{S}\right.$, $\left.149^{\circ} 11^{\prime} 06^{\prime \prime} \mathrm{E}\right)$, Blue Mtn $\left(21^{\circ} 36^{\prime} \mathrm{S}, 148^{\circ} 58^{\prime} \mathrm{E}\right)$, Mt Dryander $\left(20^{\circ} 15^{\prime} \mathrm{S}, 148^{\circ} 33^{\prime} \mathrm{E}\right)$, Conway Range $\left(20^{\circ} 21^{\prime} \mathrm{S}\right.$, $\left.148^{\circ} 41^{\prime} \mathrm{E}\right)$, Mt Ossa $\left(20^{\circ} 56^{\prime} \mathrm{S}, 148^{\circ} 49^{\prime} \mathrm{E}\right)$, Gosford $\left(33^{\circ} 24^{\prime} \mathrm{S}, 151^{\circ} 21^{\prime} \mathrm{E}\right)$, Oakview SF $\left(26^{\circ} 07^{\prime} 23^{\prime \prime} \mathrm{S}\right.$, $\left.152^{\circ} 19^{\prime} 01^{\prime \prime} \mathrm{E}\right)$, McIlwraith Range $\left(13^{\circ} 45^{\prime} \mathrm{S}, 143^{\circ} 19^{\prime} \mathrm{E}\right)$, Pattersons Gorge $\left(19^{\circ} 20^{\prime} \mathrm{S}, 146^{\circ} 28^{\prime} \mathrm{E}\right)$.

Manuscript received 15 November 2002; accepted 22 April 2003 